\title{
Learn While You Earn: Student Teacher Experiences of a Learnership Programme Facilitated by Open Distance Learning
}

\author{
Dr RM Odendaal \\ College of Education, University of South Africa \\ Email:odendrm@unisa.ac.za
}

\section{Doi:10.5901/mjss.2014.v5n16p367}

\section{Abstract}

Since the year 2000 learnerships have been introduced in all sectors of South African society including education, as a strategy to overcome the acute skills shortage which hinders national development. A learnership is defined as work-based learning with the aim of obtaining a qualification within the South African National Qualification Framework. Unlike an internship which provides experiential workplace learning for a successful graduate, a learnership provides work-based learning for a student who is in the process of gaining a qualification. In this context Open and Distance Learning (ODL) is the ideal tuition model as it enables the student to work and learn full-time while engaged in formal study. The value of learnerships as an effective means of training teachers is generally misunderstood by teacher education providers. To overcome this gap a qualitative case study explored the value of learnerships in teacher training endeavours. The inquiry was informed by Vygotsky's social constructivist learning theory, Lave and Wenger's theory of situated learning and Kolb's experiential learning theory. Twelve participants who were engaged in a teacher learnership programme in a public primary school and who were studying for a teaching qualification through ODL were selected by purposeful sampling. Data were gathered by means of participants' written accounts of their learnership experience structured around a set of ten open-ended questions which functioned as a prompt for writing. Findings indicated the professional benefits of learnerships; drawbacks of learnerships; the personal significance of the learnership; and the role of ODL tuition in the learnership programme. It was concluded that learnerships in teacher training embody a powerful and innovative strategy to produce teachers who possess a combination of work-based and theoretical knowledge and who can help overcome the skills shortage in the education sector in South Africa.

Keywords: learnership, open distance learning, experiential learning theory, social constructive theory, written narratives

\section{Introduction}

The primary obstacle to economic growth and social equity in South Africa is the general lack of skills (Bester, 2004). According to the National Skills Development Strategy of the Department of Labour, key areas for human resource development are: prioritising critical skills for growth and development; stimulating quality training for all in the workplace; promoting employability and sustainable livelihoods through skills development; assisting new entrants to the labour markets; and improving the quality and relevance of skills (Babb \& Meyer 2005). As a strategy to overcome these areas, the Skills Development Act no. 97 of 1998 (RSA 1998) introduced learnerships in various sectors to replace the old apprenticeship programmes, which previously were limited to trade and industry (Karlsson \& Berger 2006). In this endeavour a learnership for teacher education and training was also established (Mawoyo \& Robinson 2005). However, the value of learnerships as an effective means of training teachers is generally misunderstood by teacher education providers (Potgieter 2003). To overcome this gap a qualitative case study explored the value of learnerships in teacher training endeavours.

A learnership is defined as work-based learning with the aim of gaining a suitable qualification within the South African National Qualification Framework (NQF), Level 1 to 8 (RSA 1995). A learnership should include both structured work (practical) experience and instructional (theoretical) learning. The term "learnership" is related to but not synonymous with the term "internship"; there is an essential difference (Davies \& Farquharson 2004). An internship involves a student from a university or college who has already completed his/her formal studies but still needs experiential learning to enhance chances for future employment. On the other hand, a learnership provides work-based learning for a student who is the process of gaining a qualification, either an initial qualification or a different qualification required for retraining (Department of Social Development 2008). Thus, a learnership implies going to work, obtaining experiential learning and formal study (Potgieter 2003). Students engaged in a learnership enter into a tripartite agreement or learnership contract for a specific period between themselves as learners, an employer and a training 
provider, such as a university or college. The contract clearly indicates terms of reference as well as termination conditions (Department of Social Development 2008). As already mentioned the new system of learnerships in South Africa is not restricted to a specific trade, which makes learnerships a possibility as an alternative teacher education and training route in the education sector. Learnerships conducted in schools give student teachers engaged in initial or inservice teacher training the opportunity to learn to deal with the realities of the classroom situation while studying for a qualification in teaching (Department of Social Development 2008). Thus, learnerships as an innovative mode of teacher education and training partly meet the pressing need for qualified teachers in South Africa, while at the same time benefitting schools which are also in need of essential help even if the student teacher is still "in-training". In this context, Open and Distance Learning (ODL) is an ideal delivery mode for the formal tuition involved in learnerships as it allows student teachers to "learn while they earn", that is, study for a teaching qualification while at the same time employed in the school (Moran \& Rumble, 2004; Bartram, Tanuvasa \& Williams, 2004; Sargant, 2004). In this regard, the University of South Africa (Unisa), the only and the largest dedicated ODL institution in Southern Africa, offers a unique opportunity for student teachers to gain practical classroom experience whilst also studying towards a qualification in teaching (Muller \& Lemmer 2012), thus comprising a legitimate situated learning experience (cf Lave \& Wenger 1991). Certain other South African universities and independent registered teacher training institutions also have units for ODL, albeit on a limited scale (Botha 2011).

Against this background, this article reports on a qualitative case study which explored the value of learnerships through the lived experiences of student teachers who were engaged in a learnership programme in a public secondary school and who were studying for a teaching qualification through ODL. The participants had opted for a learnership supported by ODL as a suitable alternative to conventional teacher training offered on site at a residential university. The study was conducted with the aim of making recommendations for the improvement of learnerships in initial and inservice teacher training.

\section{Theoretical Perspectives on Learnerships}

In order to frame and inform the qualitative case study, this article draws on key learning theories particularly applicable to the aim and nature of learnerships as a strategy for human resource development. In this regard I discuss Vygotsky's (1978) social constructivist learning theory, the situated learning theory developed by Lave and Wenger (1991) and Kolb's (1984) experiential learning theory.

Vygotsky's (1978) social constructivist learning theory stresses the fundamental role of social interaction in learning. Vygotsky's central concept is the Zone of Proximal Development (ZPD) which is defined as "the distance between the actual developmental level as determined by independent problem solving and the level of potential development as determined through problem solving under adult guidance, or in collaboration with more capable peers". Vygostky (1978) proposed that human development is a social process in which learners use more capable persons to advance their own intellectual or skills development. Learning and development are dynamic processes that result in gaps in the learner's development level that must be filled through social cooperation and interaction with others (Vygotsky, 1978). This theory applies to the learnership situation in which more knowledgeable and skilled mentors available both in the workplace and in the formal tuition situation in which the learner is enrolled for the purpose of attaining a qualification, can assess the students' levels of knowledge and skill and capabilities (the ZPD) and assist them to achieve their potential through the acquisition of both practical and theoretical knowledge.

Associated with Vygotskyan theory which highlights the influence of the social engagements in which learners are involved on their thinking and actions, is the situated theory of learning developed by Lave and Wenger (1991; 2003). This theory emphasises both social interaction and the situated nature of learning. The authors (1991) propose that learning cannot be separated from the context or activity in which it occurs. Thus, learning takes place in a "community of practice", which is characterised by people "who engage in a process of collective learning in a shared domain of human endeavour" (Wenger 1998). Communities of practice are defined as "groups of people who share a concern for something they do and learn how to do it better as they interact regularly" (Wenger 2000). A community of practice differs from a community of interest or a geographical community in that involves a shared practice. For a community of practice to function it needs to generate a shared repertoire of ideas, routines, vocabulary and symbols which reflects the accumulated knowledge of the said community. In other words it involves the practice of ways of doing and approaching things that are shared, to a significant extent, among members (Lave \& Wenger 2003). Within a community of practice the novice participates on the periphery of the community, but moves to more central and legitimate participation as his/her skills develops. In the context of this article, student teachers in a learnership function within a community of practice, the school community enriched by the formal tutors/mentors who deliver instructional content for the 
qualification. Thus, the structure and nature of the learnerships in schools is interdependent on two different kinds of communities of practice: the university or college (which in this case delivers its programme through ODL) and the school (which provides experiential learning guided by more experienced teachers in the authentic workplace setting). However, the goal for the learner teacher remains the same in both communities of practice, namely the acquisition of knowledge and skills with a view to professional competence. Therefore, both communities should take cognisance of each other and link through recognition of each other's role in achieving the success of its end product, that is, a competent and qualified teacher.

Where the other two theorists emphasised the social nature of learning, Kolb's (1984) experiential learning theory (ELT) rests on a four-stage learning cycle: experiencing, reflecting, thinking, and acting. In stage one immediate or concrete experiences provide the basis for learning. In stage two the learner observes and reflects on this first-hand experience to guide future learning. In stage three what has been learned is assimilated or incorporated into abstract concepts based on reflection which produces new implications for action. During the fourth stage, known as active experimentation, the learner actively tests new knowledge and new experiences which in turn accommodates or creates new experiences or new concepts. Ideally the learners should experience the whole cycle of learning moments for authentic learning to occur. When the learner is faced with a different set of circumstances, he/she can anticipate the possible effects of action, which pre-empts action and new experience and thus the spiral is repeated. Experiences are either enriched or improved upon in a way that is seen as new and innovative. Two aspects in this theory are noteworthy: the use of concrete experience to test ideas and the use of feedback from a more experienced mentor or teacher so that the learner is guided to adjust practices and theories (Kolb, 1984). According to Kolb (1984) experiential learning thus involves a "direct encounter" with the phenomena being studied rather than merely thinking about the encounter, or only considering the possibility of doing something about it. Kolb's theory can be aptly applied to learnerships in schools where student teachers have a chance to acquire and apply theoretical knowledge and develop skills in an immediate and relevant setting, the classroom and where they are guided by an experienced teacher who acts as mentor.

\section{Method}

Against this background, the value of learnerships in teacher education and training using ODL as tuition mode was investigated by means of a qualitative case study. Fraenkel and Wallen (2010:430) explain that a case study "comprises just one individual, classroom, school, or program where a detailed study is made, and as much information as possible would be collected." In this case I was primarily interested in understanding a specific situation or individual, that is the lived experiences of student teachers at a particular school who were simultaneously studying for a teacher qualification through an ODL institution. Purposive sampling was used to select an appropriate learnership programme located in a multicultural English medium public secondary school in Pretoria, South Africa. Purposive sampling, also known as judgement sampling, aims at locating information-rich individuals or cases, that is, those who are likely to be knowledgeable and informative about the phenomena under investigation (Johnson \& Christensen, 2000). Access for the research was granted by a gatekeeper who I had met in my capacity as teacher educator in an ODL institution; permission for the study was granted by the school principal. Participants included twelve student teachers who had already successfully completed a year in the learnership programme at the time of data gathering. Eleven student teachers were in the age range, 22 to 28 years; one student teacher was in her early 40s. This age range is typical of ODL students who are generally mature students (Muller \& Lemmer 2012). All participants with one exception were women. Participants were involved in different subject areas and all were enrolled for a degree in teaching at teacher education institutions which provided ODL delivery. Contractual obligations of the learnership programme at the school were captured in a learnership contract between the school and the individual student teacher. Student teachers were each assigned an experienced teacher as a mentor for the year; however, this arrangement was flexible and changes could be made. Further in the course of the year student teachers were exposed to all the regular activities that make up a school community. Involvement in the study was voluntary and participants were assured that privacy and anonymity would be protected by the use of pseudonyms and omission of information that could lead to identification. Data was gathered by written accounts of approximately three pages in length in which participants described their learnership experience structured around a set of ten open-ended questions which acted as a prompt for writing. I developed the questions based on the literature and my observation of the learnership programme. However, participants were not limited to these questions and could add any information that they deemed significant. Solicited personal documents, such as these accounts, which focus on perception and meaning, comprise a useful research strategy research in qualitative research (McMillan \& Schumacher 2010). According to Johnson and Christensen (2000), personal accounts are classed as a noninteractive data gathering strategy and are a legitimate source of vivid and detailed data. 
Noninteractive strategies require little or no interaction between a researcher such as written material (e.g. journals, essays, letters, self-reports or e-mail); nonparticipant observation; photographic material; artifacts and physical trace collection (LeCompte \& Preissle, 1993). In this research, the written responses were considered a first-person document, which "describes an individual's actions, experiences and beliefs" about a particular phenomenon (McMillan \& Schumacher, 2010:361). Data analysis followed the following steps. I read and reread the accounts independently and tentative themes were identified. Firstly relevant extracts in the text were highlighted and then grouped without comment under themes (Delamont, 2002). Thereafter the themes were clustered into categories and suitable quotations were selected as rich data to illustrate the categories. Trustworthiness of interpretation was done by checking with participants to clarify issues or to ask for more information; cross-checking with a second researcher who provided expert opinion; and checking against my lengthy observations of the learnership programme undertaken in professional involvement as teacher-educator employed in higher education. Furthermore, the limitations of this case study are acknowledged. The inquiry was limited to a learnership programme in a single school and the findings are not generalisable in any way.

\section{Findings}

Four major categories emerged from the analysis of the participants' responses: professional benefits of the learnership; drawbacks of the learnership; the personal significance of the learnership; and the role of ODL tuition in the learnership programme.

\subsection{Professional benefits of the learnership}

Participant accounts confirmed that during the learnership the student teachers continuously obtained a wealth of firsthand experience of learning and teaching in the classroom as well as an understanding of the functioning of the school as organisation. This all constitutes invaluable workplace experience. A participant commented, "The learnership programme taught me a set of skills such as discipline, class organisation, administration and social skills as it pertains to learners." Another participant agreed that "The most important aspect of being an assistant teacher is gaining the whole experience of teaching." Through the simultaneous engagement in theoretical learning and experiential learning, participants were able to apply theory to practice far sooner than a novice teacher who had followed a conventional teacher training route with only short periods of practical teaching. The participants daily tested their new skills in the realworld setting. A participant observed: "Seeing an experienced teacher teaching and learning and the different techniques taught at university implemented in the class gives one a better understanding of what is being said in textbooks."

This exposure to the school and to the teaching profession helped student teachers to consolidate their career choice. Learnership thus provided a reliable way of finding out about the demands of the intended career and determining a good fit between the individual and the envisaged occupation. Interestingly, as a result of the learnership, one participant concluded that teaching was not the profession that she would like to pursue. Although she had enjoyed her year at the school and had learned much about being a teacher, she found that the experience "taught me a lot about myself and who and what I want to be. I do not want to be a teacher. This programme showed me what this profession is all about and forced me to decide if I want to remain in this profession or not. " As a result she had decided to start a career in economics in the following year. Conversely other participants were persuaded by their experience in the learnership that teaching was indeed the career for them. This was particularly pertinent to those participants who had already been employed in other sectors. Two participants, one who had studied accounting and the other a stockbroker, had thrived in the school context and they both were excited about their newfound career. In both these cases the learnership involved re-training for another qualification. In this regard a participant commented: "I came from the financial industry and throughout the year learnt about the dynamics at the school as well as the practicalities of being a teacher, a mentor and ä sporting coach and I learnt about the affection and care between colleagues and children, which convinced me even more that I wanted to teach". This opportunity to establish clearly if teaching as a career path is indeed the one to be followed is a significant benefit, whereby a student saves time and money and avoids the disappointment and disillusionment which are natural outcomes of a misguided career choice. A participant summed this up, "You either are a teacher in your blood and soul or you are not. Nothing you learn in a book can make a difference to this." Moreover, the learnership gave student teachers the opportunity to "test" which phase of schooling they preferred to teach, allowing they have to specialise in a school phase at an early stage of their career and enrol for the relevant university subjects in their degree.

Furthermore, school principals and school governing bodies as employers are often as concerned about an aspirant teacher's work experience as they are about his or her credentials. Through the learnerships the student was 
able to accrue the desired work experience while at the same time obtaining the necessary qualification needed to secure a position in a school. A participant noted the advantage she had gained by pointing out, "No amount of 'booksmart' can add up to the experience I have gained of teaching." The school principal of the participating school openly favoured the appointment of students who had undertaken the learnership programme and who had thus gained relevant experience of the ethos of his school over the hiring of total strangers. Participants were well aware that the learnership had given them an edge if they decided to apply for a teaching post at the school as this comment illustrates: "Learnership gives me a head start over other applicants." The learnership had comprised a thorough induction into the school: student teachers had been acculturated into the values of the school and had been familiarised with the principal and management team's leadership style, staff collegiality and parent partnerships. Whether they were appointed in future at this or another school, they felt that the learnership experience facilitated the transition to the school as working environment, making learnerships an important form of professional orientation.

\subsection{Drawbacks of the learnership}

Participation in a learnership is not without its challenges and student teachers were confronted with the pressure created by the constant demands of a busy school community. Entry into the school setting brought student teachers face to face with the daunting complexity of classroom interaction with children who differ in race, ethnicity and language backgrounds, the rules and routines necessary for maintaining an orderly classroom, the requirements of the curriculum and responsibilities for extra-mural activities, such as sports and cultural activities. One participant confessed to making several mistakes during the first school term; this left her insecure and she felt somewhat incompetent in the unfamiliar environment.

Participants also found that the quality of the mentorship relationship between them and the mentor teachers assigned to them was integral to the success of the learnership. A participant described a good mentor as "someone who does understand that the teaching environment is completely new to you and that it may seem bewildering and overwhelming". The importance of a good mentor teacher cannot be overestimated. The quality of the mentor-student teacher relationship largely determines the success of the mentorship in gaining future teachers for the teaching profession or losing them. One participant referred to the negative impact of a poor mentor relationship in which the mentor failed to follow a planned, systematic schedule of learning opportunities. However, the learnership programme accommodated the potential mismatch of student teacher and mentor and the participant was placed with another teacher in her second term who was more receptive towards learnership students and involved her in all aspects of the teaching experience. In this new relationship the participant regained her enthusiasm, found her place and developed confidence to "shine in my subject."

Furthermore, if the roles and responsibilities of mentor teacher and student teacher are not articulated, the student teachers may find that they either lack sufficient learning experiences or they may be overloaded with too many routine activities. Exploitation of the learnership situation then occurs as a participant explained, "I was doing all the awful work that the teachers did not want to do." This drawback highlights the importance of a formal written learnership contract with the school. In this case study formal learnership agreements were indeed concluded. Student teachers at the school were not limited to interaction with a single mentor and they had ample chance to cooperate with various teachers over the course of the year which meant that, on the whole, they were exposed to good practice. Participants confirmed that the teaching staff at the school role modelled commitment, specialised knowledge and skills, creativity and a strong work ethic. However, this discussion emphasises the need for all teachers and support staff, including administrative and ground staff, to be fully informed of the mutual rights and responsibilities of the student teacher and of the school. The learner and parent body should also be apprised of the role that student teachers have been allocated in the school.

Another drawback lay in instances where mentor teachers and student teachers did not communicate regularly and openly about expectations. One participant remarked: "It would be nice to have more meetings between teacher and student to avoid misunderstandings." This highlighted the importance of the school leadership in monitoring and managing the learnership programme. Regular report back to the school principal and management team is essential to make sure that the learnership remains relevant to student teachers and to mentor teachers. The learnership programme should be flexible enough that modifications to the student teachers' daily programme can take place to ensure that they gain experience in the their chosen fields of expertise, such as school phase and subject areas. Some participants felt that they were ready to take on greater classroom responsibilities and were denied the opportunity by the more cautious mentors. However, student teachers are not yet qualified teachers and their participation in teaching and class organisation should be tailored accordingly. Participants particularly appreciated mentors who allowed them to progress from minimal engagement in the classroom contact to increasing autonomy as they made gains in confidence. 


\subsection{Personal significance of the learnership}

Participants mentioned several personal benefits of the learnership programme. Learnership involvement boosted students' self-confidence as far as standing in front of a class and coping with large groups of learners. The presence of mentor teachers in the classroom provided student teachers with a safe environment in which they could experiment with a wide repertoire of instructional strategies and different styles of teaching. Self-confidence also fostered self-knowledge and participants came to understand themselves better. A participant remarked, "Learning is another characteristic of this programme. Learning from my teacher, learning from the class, learning more about myself." Furthermore, since student teachers remained at the school for the entire school day, they became acquainted not only with the scholastic environment but also the extra-curricular activities. Student teachers found coaching sport or assisting with cultural activities a source of self-fulfilment. Involvement with learners in the more informal setting nurtured compassion and care as a student participant elaborated, "[I learned] to handle problem children with problems at home and I learnt in what circumstances children can and cannot learn". This contributed to a deeper insight into the intricacies of teaching and student teachers became aware that the reality differs from the abstract ideal of teaching as presented in textbooks. The secure environment in which learnership takes place, in which a student teacher may turn to an experienced colleague at any time for assistance, wove a safety net in which student teachers could bond with learners and learn to deal with difficult learners.

Furthermore, student teachers were included in school assemblies, staff meetings and administrative activities and this enhanced their motivation and a feeling of belonging and encouraged a sense of "ownership" of the school. Student teachers mentioned that they had learned to collaborate with different types of personalities in the work environment, to manage minor conflict and to interact positively with difficult learners, thus improving their interpersonal skills. Participants found personal satisfaction in developing a strong work ethic, discovering their leadership potential, learning to be openminded about change and to tolerate different opinions. Another source of great personal gratification during the learnership was the camaraderie that developed with the other student teachers. Student teachers learned to network with their peers, work in teams and to share ideas and experiences. All in all, the contribution of the learnership programme to personal job satisfaction is captured in the following remark; the precious implication of the learnership experience to students can also be illustrated through this remark: "I was always happy to wake up every morning and to go to school."

\subsection{Role of ODL tuition in learnerships}

A requirement of the learnership was the participants' involvement in studying for a degree in teaching through an ODL institution, a university or an accredited college. The greatest advantage of ODL was that the students could study while working full time at the school. They did not have to take release time from the school day to attend lectures and they were also able to earn a small salary. The following comment substantiates the appeal of ODL which offers students the best of both worlds: "Instead of sitting at home completing my studies, I decided to work while I study and found my place and confidence to shine in my subject". The engagement in ODL opened participants' eyes to the possibility of lifelong learning. They realised that the completion of the learnership did not necessarily have to herald the end of their studies. Through ODL they would be able to undertake postgraduate studies in future as part of continuous professional development without disturbing the career trajectory they had embarked upon.

Furthermore, the combination of study and practical teaching made the theoretical sphere come alive. A participant reflected, "Getting this teaching experience I found that I understood my theoretical work better." While a solid academic foundation was laid by the ODL institution, new teaching techniques could be immediately implemented and theoretical knowledge about children could be immediately tested. A participant applauded the situation by saying, "Working whilst studying gave me the opportunity to experiment and implement what I am learning theoretically." The participants were generally satisfied with the quality of instruction offered by the ODL institutions. Lecturers had been informed that these student teachers were participating in the learnership and lecturers and participants were able to communicate by e-mail or phone and during on-site visits made by lecturers to the school. Participants also felt that the quality of their assignments and projects were enhanced by experiential learning: they were able to draw on their experience in the school and illustrate theoretical points with concrete examples which frequently earned them better grades.

\section{Discussion}

The findings suggest that the learnership for teacher training combined with the advantages of ODL tuition as presented 
in this paper offered participants several benefits. Their experiences of the learnership demonstrated how effectively individuals learn by becoming part of a community of practice through legitimate peripheral participation (Lave \& Wenger 1991). Through the participants' incorporation into the school for an extended and uninterrupted period of time (the annual four-term school cycle), they integrated fully into the school as a community of practice characterised by the same beliefs, values and practices, and they developed work-related skills through actual experience. Teachers who were seasoned practitioners provided coaching and learning took place almost unintentionally through the observation and participation in "real life" situations (Lave \& Wenger 1991; Lave \& Wenger 2003; Wenger 1998). Gaps in participants' knowledge and skills were filled in during collaboration with the more knowledgeable teachers (Vygostky 1978) who, as mentors, were essential partners in the learning process. Where there was a mismatch with a mentor teacher, as in one instance, the learnership foundered. This emphasised the importance of social interaction marked by emotional support and successful communication to nurture the student-teacher and teacher-mentor relationship. Further, while functioning in the school community student-teachers, as active participants, began to construct identities in relation to this community which, according to Wenger (1998), is a central aspect of learning. All the participants, with one exception, came to identify with the teaching profession and this consolidated their career choice. Moreover, the experiential learning that took place in the school as community of practice was connected with the ODL institution which also represented a community of practice, separate yet interlinked and both communities enriched the student-teachers' acquisition of pedagogical skills (Wenger 1998). Further, combination of experiential learning with the ODL teacher training programme created optimal conditions for realisation of Kolb's (1984) learning cycle. In the workplace student teachers gained experience by participating in the activities of the classroom. Their reflection on this experience was further informed by their theoretical studies and they could attribute meaning to their experience through analysis and conceptualisation. Based on this they could make choices on further steps leading to the next learning experience.

Based on this study recommendations towards better learnership practice include the introduction of a short induction period where students are introduced to the school before casting them immediately into the classroom. During an induction students and mentor teachers learn to know each other informally and mutual expectations can be clarified before the commencement of the reality of classroom practice. This can go far to avoid a mismatch of student and mentor. Visits to the classrooms of other mentor teachers will expose students to different teaching styles and thus encourage the development of a critical, progressive philosophy of teaching and learning. Training and selection criteria for identifying mentor teachers is another recommendation to prevent interpersonal tension or substandard mentoring. Further, based on the components of a successful and ongoing learnership programme such as the one described, a standard model can also be developed so that the programme is constant in each school. Information could be shared between schools, either in the area or nationally, towards delivering an improved program. Finally, closer cooperation between university supervisors from the ODL institution and the school is suggested as well as clear procedures for school visitation by university supervisors. Thereby, closer ties among the university, schools and student teachers can be established.

\section{Conclusion}

Although the findings of the case study presented in this paper are not generalisable, the emerging themes demonstrate the benefits of a well-established learnership programme. Facilitated by a flexible ODL mode of tuition delivery, learnerships for teacher training can provide an innovative strategy to overcome the skills shortage in education and produce teachers who possess a combination of work-based and theoretical knowledge and who enjoy high levels of job satisfaction.

\section{References}

Babb, S. \& Meyer, T. (2005). Perspectives in learnerships: South African case studies. Randburg: Knowres Publishing.

Bartram, J.P., Tanuvasa, I. \& Williams, J. (2004). Distance learning for vocational education and training in the small island states in the Pacific. In Moran, L. \& Rumble, G. (eds.), Vocational Education and Training through Open and Distance Learning (pp. 99-112). London: Routledge Falmer.

Bester, G. (2004). Further education and training in South Africa. In Moran, L. \& Rumble, G. (eds.), Vocational educational and training through open and distance learning (pp.113-124). London: Routledge Falmer.

Borzak, L. (1981). Field study. A source book for experiential learning. Beverly Hills: Sage Publications.

Botha, J.C. (2011). The role of higher education policy in distance education provision in South Africa. Unpublished D Ed thesis, University of South Africa, Pretoria.

Curran, C. (1997). ODL and the traditional universities: dichotomy or convergence? European Journal of Education, 32(4), 335-346. 
Davies, T.A. \& Farquharson, F. (2004). Implementing learnerships: learner recruitment and selection from the KwaZulu-Natal pilot projects. South African Journal of Higher Education, 18 (1), 336-352.

Delamont, S. (2002). Fieldwork in educational settings: methods, pitfalls and perspectives. (2nd ed.). London: Routledge.

Department of Social Development. (2008). Human resource development internship and learnership policy: Province of the Eastern Cape.

Fraenkel, J.R. \& Wallen, N.E. (2010). How to design and evaluate research in education. (7th ed.). New York: McGraw-Hill.

Haughey, M., Faroquque, A.M., Hensley, D., \& Robinson, B. (2004). Learning for and in the workplace. In Moran, L. \& Rumble, G. (eds). Vocational Education and Training through Open and Distance Learning (pp. 183-202). London: Routledge Falmer.

Johnson, B. \& Christensen, L. (2000). Educational research: quantitative and qualitative methods. Boston: Allyn \& Bacon.

Karlsson, J. \& Berger, M. (2006). Well-grounded and prepared new teachers: Reflecting on the promise of learnerships. Perspectives in Education, 24(1), 53-64.

Kolb, D.A. (1984). Experiental learning: Experience as the source of learning and development. New Jersey: Prentice-Hall.

Lave, J. \& Wenger, E. (1991). Situated learning: Legitimate peripheral participation. Cambridge: University of Cambridge Press.

Lave, J. \& Wenger, E. (2003). Communities of practice. Encyclopaedia of Informal Education, 1:1-8.

LeCompte, M.D. \& Preissle, J. (1993). Ethnography and qualitative design in educational research. (2nd ed.). San Diego: Academic Press.

Lemmer, E.M. \& Muller, H. (2011). Student satisfaction with short learning programmes at a distance learning institution. African Education Review, 8(3), 20-37.

Le Cornu, P., Van der Merwe, G., Moore, D., Nduba, S. \& Rennie, F. (2004). Institutional policy for vocational education and training delivery. In Moran, L., \& Rumble, G. Vocational Education and training through Open and Distance Learning (pp. 164-182). London: Routledge Falmer.

Mawoyo, M. \& Robinson, M. (2005). The organisation of pedagogy in a learnership model of teacher education. South African Journal of Education, 25(2), 109-114.

McMillan, J.H. \& Schumacher, S. (2001). Research in education: A conceptual introduction. (5th ed.) United States: Priscilla McGeehon.

Moran, L. \& Rumble, G. (2004). Vocational education and training. In Moran, L. \& Rumble, G. (eds.) Vocational Educational and training through Open and Distance Learning (pp.1-14) London: Routledge Falmer.

Lemmer, EM \& Muller, H. 2011. Student satisfaction with short learning programmes at a distance learning institution. African Education Review, 8 (3): 20-37.

Potgieter, F. (2003). Phantomship or ferryboat? Understanding the mystery of learnerships and assessing the realities. Perspectives in Education, 21(1), 167-187.

Republic of South Africa (RSA). (1998) Skills Development Act no. 97 of 1998. Government Gazette, vol. 401, no. 19420. Cape Town: Government Printers.

Republic of South Africa (RSA). (1995) South African Qualifications Authority Act No 58 of 1995. Government Gazette, vol. 357 , no. 16725. Cape Town: Government Printers.

Sargant, N.E. (2004). Vocational education and training through open and distance learning in the United Kingdom, 1970-2003. In: Moran, L. \& Rumble, G. (eds). Vocational Education and Ttraining through Open and Distance Learning (pp. 127-146). London: Routledge Falmer.

Vygotsky, L.S. (1978). Interaction between Learning and Development. In Mind in society: development of higher psychological processes (Trans. M. Cole) (pp.79-91). Cambridge, MA: Harvard University Press.

Wenger, E. (1998). Communities of practice: learning as a social system. SystemsThinker. [Online] Available: http://co-jI.com/coil/knowledge-garden/cop/lss.html (accessed on 6 January 2014).

Wenger, E. (2000). Communities of practice and social learning systems. Organization, 7(2), 225-246. 